Int. J. Dev. Biol. 57: 611-620 (2013)

doi: $10.1387 / \mathrm{ijdb} .130238$ ri

\title{
Transfer of knowledge about flowering and vegetative propagation from model species to bulbous plants
}

\author{
HENDRIKA A.C.F. LEEGGANGERS ${ }^{1, \#, ~ N A T A L I A ~ M O R E N O-P A C H O N ~}{ }^{1, \#, ~ H E N K ~ G U D E ~}{ }^{2}$ \\ and RICHARD G.H. IMMINK*,1 \\ ${ }^{1}$ Physiology of Flower Bulbs, Department of Plant Physiology, Wageningen University, Wageningen, and ${ }^{2}$ Flower \\ Bulbs, Applied Plant Research, Wageningen University \& Research Centre, Lisse, The Netherlands.
}

\begin{abstract}
The extensive characterization of plant genes and genome sequences summed to the continuous development of biotechnology tools, has played a major role in understanding biological processes in plant model species. The challenge for the near future is to generate methods and pipelines for an efficient transfer of this knowledge to economically important crops and other plant species. In the case of flower bulbs, which are economically very important for the ornamental industry, flowering time control and vegetative propagation constitute the most relevant processes for agronomical improvements. Those processes have been reasonably studied in reference species, making them excellent candidates for translational investigations in bulbous plant species. The approaches that can be taken for the transfer of biological knowledge from model to non-model species can be roughly categorized as "bottom-up" or "top-down". The former approach usually goes from individual genes to systems, also known as a "gene-by-gene" approach. It assumes conservation of molecular pathways and therefore makes use of sequence homology searches to identify candidate genes. "Top-down" methodologies go from systems to genes, and are e.g. based on large scale transcriptome profiling via heterologous microarrays or RNA sequencing, followed by the identification of associations between phenotypes, genes, and gene expression patterns and levels. In this review, examples of the various knowledge-transfer approaches are provided and pros and cons are discussed. Due to the latest developments in transgenic research and next generation sequencing and the emerging of systems biology as a matured research field, transfer of knowledge concerning flowering time and vegetative propagation capacity in bulbous species are now within sight.
\end{abstract}

KEY WORDS: bulbous plant, flowering time control, vegetative propagation, gene regulation

\section{Introduction}

In the last decade the establishment of full genome-sequences and the development of new biotechnology tools have dramatically increased our knowledge of plant functioning. For example, the genome sequence of Arabidopsis ( $130 \mathrm{Mbp}$; dicot), rice ( $\sim 380$ $\mathrm{Mbp}$; monocot) and maize ( $2500 \mathrm{Mbp}$; monocot) were completed in 2000, 2002 and 2009, respectively (AGI, 2000, Schnable et al., 2009, Sequencing Project International Rice, 2005). Molecular biology, genomic and transgenic research, such as loss-of-function mutagenesis and overexpression studies, have played a key role in exploiting and understanding biological and molecular functions of the thousands of genes present in the genome sequences.
Nonetheless, the majority of these functional studies have been performed in plant model species, such as Arabidopsis, Medicago and rice. All together this provided a wealth of knowledge on the control of a large variety of biological processes and traits. Hence, the road has been paved for the implementation of this data and the transfer of knowledge from model species to relevant but less

Abbreviations used in this paper: BLAST, basic local alignment search tool; cDNA, complementary deoxyribonucleic Acid; EST, expressed sequence tag; MADS, $\mathrm{Mcml}$ agamous deficiens serum response factor; Mbp, millions of base pairs; NGS, next generation sequencing; PCR, polymerase chain reaction; RNA, ribonucleic acid; SAM, shoot apical meristem; T-DNA, transfer-DNA; VIGS, virus induced gene silencing.

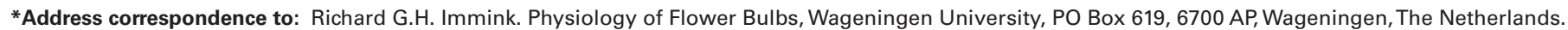

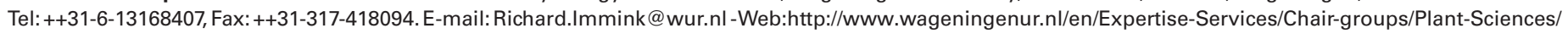
Laboratory-of-Plant-Physiology/Research/Physiology-of-Flower-Bulbs.htm

\#Note: Both authors contributed equally to this work

Final, author-corrected PDF published online: 16 October 2013.

ISSN: Online 1696-3547, Print 0214-6282 
studied crop species, ultimately aiming to improve and optimize yield and quality for a sustainable agriculture.

Almost all bulbous plant species are monocots, including the economically important ornamentals tulip and lily. Bulbous plants are hardly studied at the molecular and biotechnological level and therefore this review will have a special focus on these species. Bulbous species were introduced in Western Europe in the $16^{\text {th }}$ century and are nowadays primarily utilized for commercial bulb production, garden and forced fresh cut flower production and for landscape architecture. Cultivation occurs in temperate climate regions with the Netherlands being the leading producer world-wide. In total, seven species dominate the industry consisting of Tulipa, Lilium, Narcissus, Gladiolus, Hyacinthus, Crocusand Iris(Benschop et al., 2010). Flower bulbs propagate sexually through seeds and vegetative via initiation and outgrowth of axillary meristems, which are usually located in the underground storage organ (Kamenetsky and Okubo, 2012). Like other plants, bulbs propagated from seeds undergo three developmental phases: juvenile vegetative, adult vegetative and reproductive. The duration of the juvenile vegetative phase can take several years (e.g. Tulipa and Narcissus) and only upon the transition to the adult vegetative phase, the bulb becomes competent for flower initiating signals. The vegetative phase switch from juvenile to adult depends on the physiological age, weight and size of the bulb. Subsequently, taking tulip as an example, high temperatures can induce the transition from adult vegetative to the reproductive phase, resulting in flower bud initiation. Simultaneously, dormancy is triggered and a pro-longed period of cold is required for dormancy release and internal preparation for stem elongation and flower outgrowth in the next spring. This specific life cycle is not only seen in tulip, but is common for various bulbous species, including Tulipa, Crocus and Hyacinthus (Kamenetsky et al., 2012, Rees, 1966, Saniewski et al., 2000).

In order to improve bulb productivity and ornamental characteristics, it is necessary to increase genetic variation by breeding new cultivars and potentially this can highly benefit from the implementation of biotechnological and 'omics' tools. Currently, the development of a new tulip cultivar can take up to 20 years because of its long juvenile phase and low vegetative propagation rate (Podwyszyńska, 2005). Besides the long juvenile phase, which slows down the breeding process and the production of flowers, an agricultural problem is laid down in the precocious flower initiation by high temperatures in spring, resulting in early development of the flower bud. Consequently the flower bud is completely developed inside the bulb around harvest time, leading to either flower abortion or a decrease of flower quality in the next season because of dehydration during storage of the bulbs (Hartsema, 1961). In addition, natural vegetative propagation rates vary among flower bulbs, but on average are low due to the limited number of axillary meristems and a restriction in outgrowth of these meristems (Kamenetsky and Okubo, 2012). Together with the long juvenile phase, this makes the development of a new flower bulb cultivar a slow and time consuming process. Many efforts in understanding and improving the physiological nature of flowering and vegetative propagation in bulbous plants took place in the last decades (Aung and Hertogh, 1979, Balk and de Boer, 1999, Beijer, 1952, Lambrechts et al., 1994, Rietveld et al., 2000); however, the majority of these studies focused on physiological factors and limited molecular and genomic studies have been performed. Although various reasons can be brought forward for this, the large genome sizes for bulbous plants (Tulip $\sim 25000 \mathrm{Mbp}$; Lily 36000 Mbp) and technical difficulties in isolating e.g. RNA from bulb scales have been particularly decisive in this (Shahin et al., 2012).

Here, we will briefly summarize the current knowledge on flowering time control and vegetative propagation gained from studies in model plant species, since these are the two most important biological processes for agronomical improvements of bulbous plant species cultivation. Subsequently, we will give an overview of approaches to transfer this type of knowledge from model plants to crop species and how transgenic and 'omics'technologies can be supportive. Various examples will be given from studies that used such a strategy, including an overview of the technologies that are relevant for bulbous plant species. In the final concluding section a prospect will be given how novel emerging technologies,

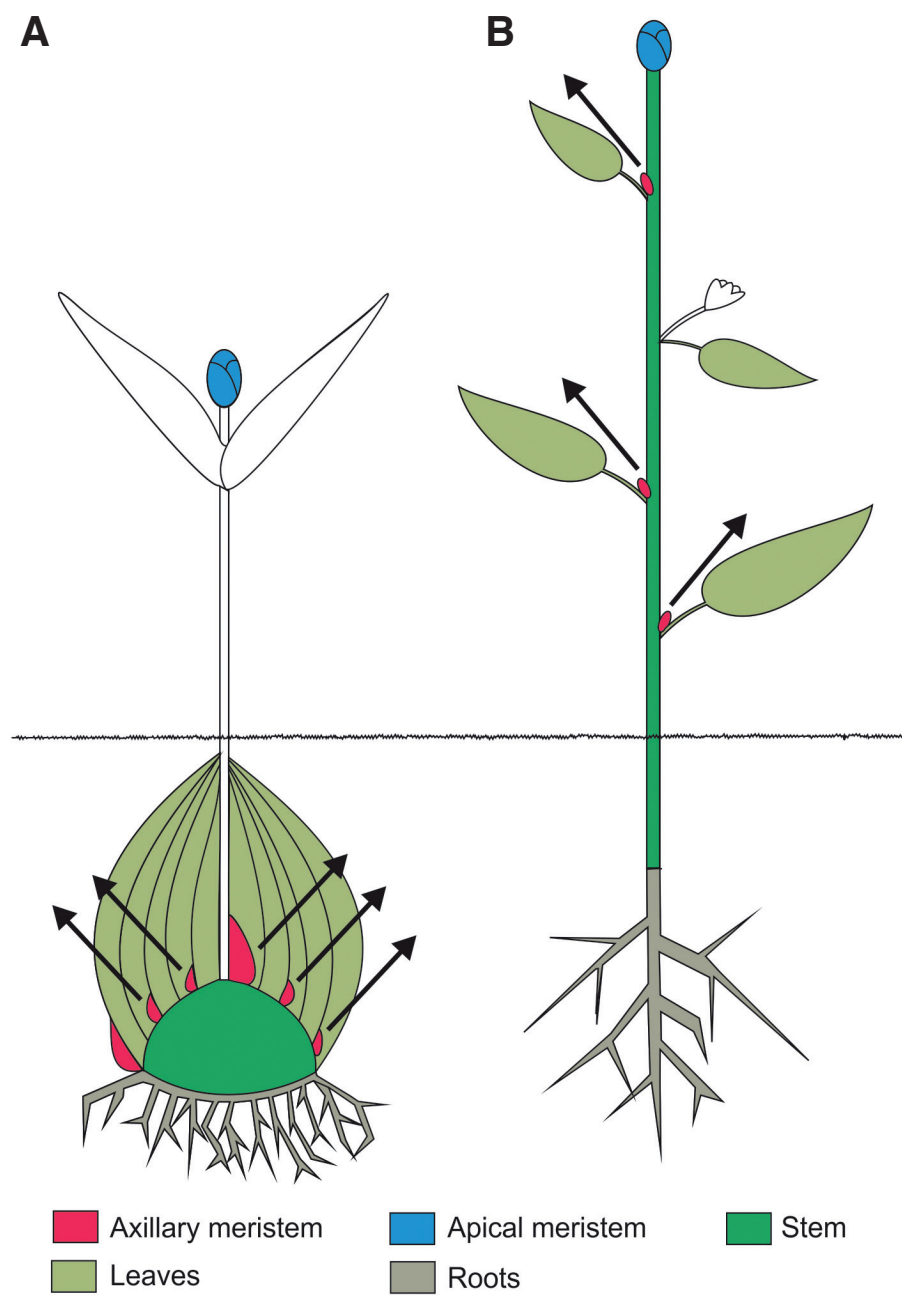

Fig. 1. Architecture of a bulbous and a non-bulbous plant. (A) Tulip, (B) model dicot plant. Initiation of axillary meristems takes place in the axils of bulb-scales (A) or leaves (B). They form a bud like structure and undergo a period of dormancy. Once bud dormancy is broken, axillary buds grow out and develop into daughter bulbs in bulbous plants, or axillary branches in a typical dicot plant. In tulip, normally only two of the axillary buds will develop into daughter bulbs and once the apical bud blooms and dies, the closest axillary bud will become the apical bud for the next season. In bulbous plants the stem is called basal plate and it is a modified stem; Bulb-scales of bulbous plants are modified leaves. Arrows represent axillary bud outgrowth. 
bioinformatics, and systems biology can increase the efficiency and strength of this type of research and move the field from geneby-gene approaches into a comprehensive genome-wide level.

\section{What is known about flowering and vegetative propaga- tion from model systems}

Although the best studied model system, Arabidopsis, is a dicot, and the majority of bulbous plant species are monocots, the regulatory mechanisms underlying important agricultural traits appeared to be conserved in various cases. Hence, knowledge gained in Arabidopsis can be informative for studies in bulbous plants. Strong conservation between Arabidopsis and the monocot rice was observed e.g. for the genes involved in the photoperiod flowering time pathway (Izawa et al., 2003). The same holds for various hormonal signalling components and the key transcription factors involved in axillary meristem formation and outgrowth, which is directly related to vegetative propagation capacity in bulbous species (Finlayson, 2007, Kebrom et al., 2013). Nevertheless, various exceptions are known and in general best results are obtained when using a closely related model species as starting point. Therefore, we will discuss mainly knowledge gained from Arabidopsis, but when relevant, complemented with information from other dicots and monocot species.

\section{Vegetative propagation}

Shoot branching is a vegetative process determined by axillary meristems and it determines the architecture, biomass and reproductive success of a plant. Initiation of an axillary meristem results in the formation of a bud that will undergo a period of dormancy. Once the right environmental or endogenous plant factors release the bud from dormancy, it will grow and develop into a branch or a propagule in the case of flower bulbs (e.g. daughter bulb, bulblet, bulbil), a process known as bud outgrowth. Hence, the processes of axillary bud initiation and axillary bud outgrowth together determine the vegetative propagation rate in bulbous species (Fig. 1).

Several genes promoting axillary bud initiation have been identified in different model species (Bennett and Leyser, 2006, Kebrom et al., 2013) and their supposed functions could be confirmed by transgenic approaches. For instance, a transcription factor of the GRAS family characterized in tomato, rice and Arabidopsis, - Lateral suppressor (Ls), Monoculm1 (MOC1) and LATERAL SUPPRESSOR (LAS), respectively - is responsible for the establishment of an axil identity and maintenance of meristematic capacity via prevention of cell de-differentiation (Bennett and Leyser, 2006, Greb et al., 2003, Li et al., 2003, Schmitz and Theres, 2005, Ward and Leyser, 2004). A second key regulatory gene discovered in tomato, $B L I N D(B I)$, encodes a MYB transcription factor that also promotes axillary bud initiation but its function is independent of Ls. The Bl ortholog in Arabidopsis is REGULATOR OF AXILLARY MERISTEMS1 (RAX1) (Keller et al., 2006, Müller et al., 2006). A third regulator identified in Arabidopsis, REGULATOR OF AXILLARY MERISTEM FORMATION (ROX) has orthologs in rice LAX PANICLE1 (LAX1) and maize Barren stalk1 (Ba1), although the latter two also affect inflorescence branching (Yang et al., 2012). During vegetative development in Arabidopsis, LAS and RAX1 influence the expression of $R O X$ and axillary bud initiation occurs when ROX expression ceases (Yang et al., 2012). In contrast, $L A X 1$ transcripts in rice are detected only after the axillary bud has initiated (Oikawa and Kyozuka, 2009), suggesting that the molecular control of ROX-like genes may differ in timing between monocots and dicots.

Occurrence of bud outgrowth depends on the factors that release buds from dormancy. Apical dominance, which is the ability of the shoot apex of the plant to prevent outgrowth of axillary meristems, and therefore branching, is one of the most studied phenomena controlling dormancy in axillary buds. This control is mediated by a balanced hormonal signalling between auxin, cytokinin and the recently discovered strigolactones (Kebrom et al., 2013). Evidence for a role of strigolactones in axillary bud outgrowth is given by ramosus ( $r m s$ ) mutants in pea, decreased apical dominance (dad) in petunia, more axillary growth (max) in Arabidopsis, and dwarf (d) or high tillering dwarf (hdt) in rice (Booker et al., 2005, Ishikawa et al., 2005, Liu et al., 2009, Morris et al., 2001, Napoli, 1996) In Arabidopsis MAX1, MAX3 and MAX4 are involved in strigolactone biosynthesis while MAX2 plays a role in strigolactone signalling. Although the exact crosstalk between auxin, strigolactones and cytokinins in the control of shoot branching is not yet entirely understood, it is clear that auxin and strigolactones inhibit bud outgrowth while cytokinins promote it. In this system, a bud-specific gene that promotes bud arrest could be the key element to integrate the bud outgrowth pathway. Indeed, such a gene exist and is represented by Teosinte branched1 (TB1) in maize and BRANCHED (BRC1) in Arabidopsis (dicot). TB1 was first identified in maize and appears to encode for a transcription factor from the TCP family (AguilarMartínez et al., 2007). Evidence in Arabidopsis and pea show that the TB1 ortholog $B R C 1$ is up-regulated by strigolactones and down-regulated by cytokinins (Aguilar-Martínez et al., 2007, Braun et al., 2012). A more recent study supports the idea of BRC1 as a second messenger to induce and maintain bud arrest by negatively regulation of cell cycle, ribosome translation, and promotion of Abscisic Acid (ABA) signalling (González-Grandío et al., 2013). Because, outgrowth of axillary buds seems to be the major limiting factor in vegetative propagation of bulbs, the strigolactone signalling pathway and TB1-like genes are first targets of choice to study and optimize vegetative propagation in these plant species.

\section{Flowering time control and flowering induction}

Besides branching and axillary bud development, flowering time is an important trait influencing reproduction capacity in bulbous species. Plants are continuously sensing their environment, for being in the reproductive phase under optimal conditions and securing their reproductive success. Besides environmental cues, such as photoperiod and temperature, flowering time is also controlled by endogenous signals, including hormone levels and plant age (Lang, 1952). In the model plant Arabidopsis the vegetative phase transition and floral induction, are well studied at the molecular level and the complex gene regulatory networks underlying these processes have recently been reviewed (Andres and Coupland, 2012, Srikanth and Schmid, 2011). We will discuss flowering time control here only briefly, with a focus on the pathways that are the most important for flowering in most of the bulbous species (Fig. 2), which are the aging and temperature pathways. The juvenile vegetative phase (aging pathway) can take up to seven years in bulbous species. Upon reaching the adult vegetative stage, the transition to reproductive development can be induced, which in tulip e.g. is triggered by relative warm temperatures in the spring or early summer (ambient temperature pathway). However, for 
development of the floral meristem into a complete flower and for elongation of the floral stem, a prolonged period of cold is essential (dormancy release), in analogy with bud dormancy release in trees (Cooke et al., 2012).

Plant age is one of the endogenous factors that can be linked with developmental phase transitions and competence of the shoot apical meristem for environmental signals triggering flowering. The age-dependent vegetative transition in Arabidopsis is regulated by microRNA156 (miR156) and the SQUAMOSA PROMOTOR BINDING PROTEIN-LIKE (SPL) genes that are targeted by this microRNA. The repression of miR156 results in up-regulation of several SPL genes which promotes vegetative transition (Fornara and Coupland, 2009). Two recently published studies showed that miR156 levels are responding to sugars (Yang et al., 2013, Yu et al., 2013). Whereas a bulb is a storage organ and it is well known that sugars get re-located towards the shoot apical meristem and stem (sinks) upon flowering-inducing temperature changes (Lambrechts et al., 1994), it will be of interest to focus on this particular pathway in the hunt for signalling components involved in flowering time control of bulbous species.

After the switch from the juvenile to the adult vegetative phase, the plant becomes competent for flowering inducing external cues.
Furthermore, reproductive development is triggered by the activation of microRNA172 (miR172) by the SPL genes, which results in the repression of a set of APETALA2 (AP2)-like genes, acting as repressors of flowering (Zhu and Helliwell, 2011). Both microRNAs miR156 and miR172 are conserved in dicots and monocots (Axtell et al., 2007). Although, the age dependent phase transition is studied to a lesser extent in monocots (Strable et al., 2008, Tanaka et al., 2011) (Fig. 2), performed experiments reveal a high level of conservation in the regulatory mechanisms controlling flowering time in between different species.

Vernalization is the requirement for a period of prolonged cold to overcome a block on flowering in winter annual plants. In Arabidopsis FLOWERING LOCUS C (FLC) is the key floral repressor in this process, and this transcription factor was shown to act as a direct transcriptional repressor of the so-called floral integrator genes FT (FLOWERING LOCUS T) and SUPPRESSION OF OVEREXPRESSION OF CONSTANS1 (SOC1) (Fig. 2). FLC is activated by the positive regulator FRIGIDA (FRI) that acts in a large multi-protein complex. During winter, the transcriptional regulator VERNALIZATION INSENSITIVE3 (VIN3) will respond to a prolonged period of cold, resulting in its gradual activation. As a consequence $F L C$ will be repressed providing the shoot apical

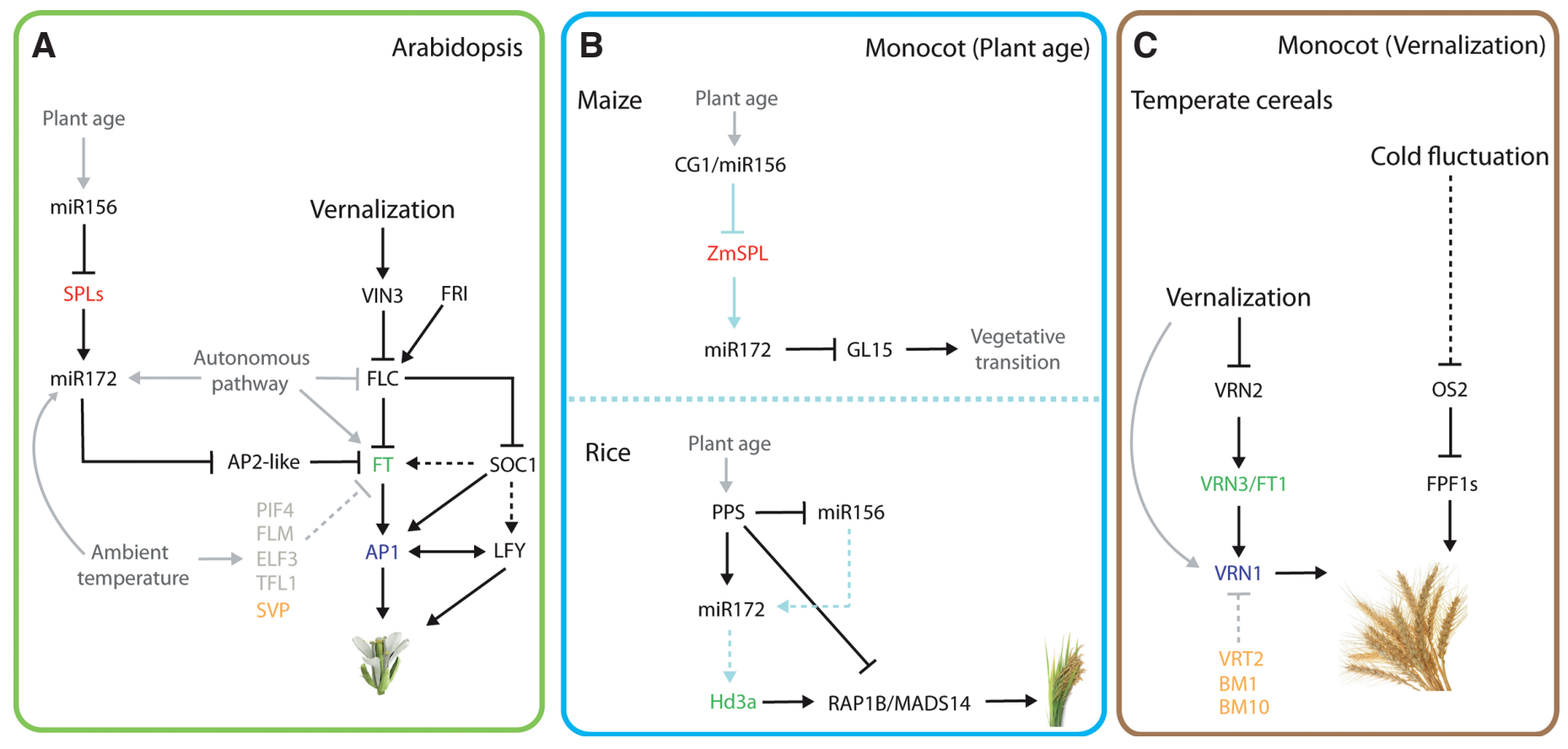

Fig. 2. Comparison of the gene regulatory networks for flowering time control in dicots and monocots. In Arabidopsis (A) upon aging miR156 is repressed leading to the up-regulation of selected SPL genes which promote the vegetative phase transition (aging pathway). External cues, e.g. ambient temperature, trigger the activation of miR172 via the SPL genes leading to the repression of the floral repressors AP2 and AP2-like genes. In order to be able to flower, winter annual Arabidopsis ecotypes first needs a pro-longed period of cold leading to the activation of VIN3 and repression of FLC. Ultimately, this results in the activation of the floral integrators FT and SOC1, followed by the activation of the floral meristem identity genes AP1 and LFY. In the monocot maize (B, top), the vegetative phase transition is regulated by the suppression of the AP2-like gene GLOSSY15 (GL15) through the activation of miR172. CORNGRASS1 (CG1) encodes miR156 and similar to Arabidopsis, might represses ZmSPL leading to the activation of miR172. In the monocot rice (B, bottom), PETER PAN SYNDROME (PPS) is involved in the repression of miR156 and the activation of miR172. This might occur directly by PPS or indirectly (dotted blue arrow) through miR156. Upon unfavourable environmental conditions, PPS represses RAP1B/ MADS14, independent of Hd3a (rice FT homolog). In monocot temperature cereals (C) the FT homolog VRN3/FT activates VRN1 upon a prolonged period of cold, leading to flowering. Nevertheless, the SVP homolog VRT2 represses VRN1. Shorter periods of cold repress OS2 which inhibits stem elongation through FPF1s. Taking into account this knowledge from model species and assuming general conservation of the gene regulatory networks, a putative flowering controlling network can be designed for bulbous species. Genes with similar kind of functions in the different species are marked with the same colour. 


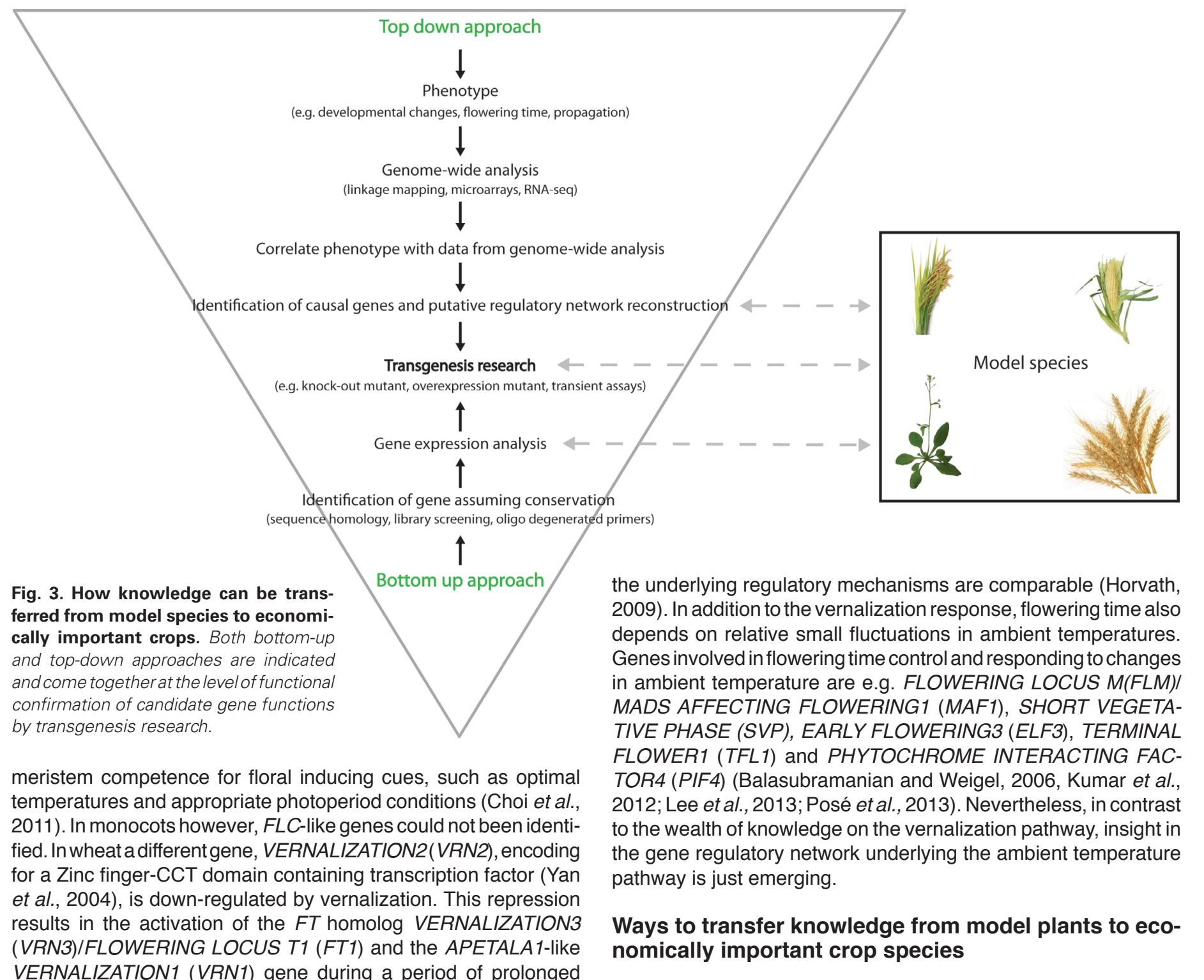

VRNALIZATION1 (VRN1) gene during a period of prolonged cold (Alonso-Peral et al., 2011, Yan et al., 2006). Three genes homologous to the Arabidopsis SVP gene; VRT2, BM1 and BM10 respectively, are able to repress $V R N 1$ but their role in vernalization or floral transition is not completely understood (Kane et al., 2005, Trevaskis et al., 2007). Besides a pro-longed period of cold (vernalization response), short cold stresses repress the grass specific MADS box gene ODDSOC2 (OS2). A proposition was made that $O S 2$ is present in a pathway that delays the transition to reproductive development and that additionally inhibits stem elongation (Greenup et al., 2010). Altogether, this suggests that the vernalization response has evolved independently in monocot and dicot plants, although members from the MADS box transcription factor family play an important role in both. Bulbous plants, such as tulip, also require a prolonged period of cold. Though, in this case it is not essential for the meristematic switch from vegetative to reproductive development, but to release dormancy in the already existing floral bud and to induce stretching of the floral stem. Despite that this dormancy release is different from the vernalization response, more and more evidence is provided that

To transfer the wealth of knowledge gained from studies in model species towards crops and e.g. bulbous plant species, diverse roads can be taken. According to the methodology used to link the molecular basis of life (e.g. genes) with biological functions, such methods can be divided in bottom-up or top-down approaches (Fig. 3). The former one uses deductive reasoning, meaning that the knowledge is built from the constitutive parts (e.g. genes) to the systems, while top-down requires inductive reasoning: from systems to causal genes.

\section{Bottom-up approach}

The start point of this approach is the identification of putative orthologues genes in crops for genes of interest in model species (Salentijn et al., 2007). In general this is based on sequence homology and the assumption that the molecular pathways underlying the control of the biological processes, and hence the involved genes, are conserved. A widely used method in the past was the identification of highly homologous genes by genomic or cDNA library screenings (e.g. (Sun et al., 1999, Xu et al., 1995)). For 
this purpose hybridization can be applied or alternatively PCRbased methods, using degenerated oligonucleotides. Once the unknown target genes are identified, they can be sequenced and subsequently compared in silico with the gene sequences from the model species. An advantage of this method is that construction of such libraries does not require a priori genome sequence information. However, to date there are only limited comprehensive genomic libraries available for flower bulb species, likely due to the complex genome sizes. When sequence information is available for the species of interest, identification of homologues is normally done in silico via BLAST-based sequence alignments (Altschul et al., 1990). However, there are limitations to the above discussed simplistic approaches, given by the fact that sequence similarity does not always imply functional similarity. This is nicely exemplified by differences in function for key genes in the vernalization pathway between monocots and dicots (e.g. AP1-like genes; Fig. 2). Furthermore, large-scale evolutionary events such as duplications can cause functional divergence for paralogues genes. When evolutionary events are taken into account, comparative studies, such as synteny mapping can provide information on orthology of the blasted sequences (McCouch, 2001). Whereas in the past, this was restricted to species for which the genome was sequenced or for which a detailed genetic map was available, integrating high-throughput Next Generation Sequencing (NGS) data makes it possible to apply this type of studies to crops that lack a reference genome sequence (Galvão et al., 2012) and hence, make it also possible to use synteny mapping for bulbous plant species in the near future. Regardless whether orthology will be taken into account, various experimental tools can be applied to guide the identification of genes or proteins with identical functions based on intrinsic characteristics of the molecules, such as protein-protein interaction capacity or their specific expression patterns.

\section{Top-down approach}

Top-down methodologies build vast amounts of high-throughput data in order to establish systems from which identifying causal genes would be feasible (Fig. 3). Large scale phenotyping platforms coupled to linkage mapping, and gene expression-based analyses, such as the generation of Expressed Sequenced Tags (EST) or genome-wide transcriptome profiling via microarray analyses or RNA-seq, are examples of sources for such large-scale data sets. EST datasets are a rich source for designing custom-made DNA microarrays (Lorenz et al., 2003), but for many species of interest there are no sufficient datasets available to create a proper microarray platform. In that case, cross-species microarrays, in which probe sequences are derived from a model species and hybridization is performed with material from a crop of interest, is an attractive alternative to profile expression patterns (e.g. (Moore et al., 2005, Wang etal., 2010)). However results have to be interpreted carefully because of variance in efficiency of probe-transcript hybridization, caused by differences in sequence similarities or e.g. number of gene copies, due to species-specific duplication events (Lu et al., 2009). Unlike classical microarray experiments, RNA-seq does not require genome sequence information (Wang et al., 2009), neither a priori knowledge of gene functions. Furthermore, the method is highly sensitive and accurate providing detailed insight in gene transcription levels, as well as splicing variants across different physiological or morphological samples. Together, these characteristics make this technology an ideal tool to gain insight in the transcriptome of bulbous plants and to study differential gene expression for relevant biological process in these species. Nevertheless, assembling the enormous amount of short reads produced by RNA-seq is a bioinformatic challenge (Martin and Wang, 2011); especially for crops that lack a reference genome, which is the case for many economically important crops and in particular for bulbous plants. In absence of a reference genome, de novotranscriptome assembly is used as first approach (Garber et al., 2011). A successful example of the latter approach, was recently presented for grapes, that like bulbous species preferably sustain through vegetative propagation (Venturini et al., 2013). Besides transcriptomics data, information from other "omics" types of approaches can be implemented. Currently, after transcriptomics the proteomics field is the most advanced and detailed quantitative information can be obtained at the protein level (Bindschedler and Cramer, 2011, Kaufmann et al., 2011). Also metabolomics is improving, but generated datasets are more fragmented and improvements of both throughput and reproducibility are needed (Saito and Matsuda, 2010).

The next step for all above mentioned top-down approaches, aiming to obtain information on gene activity and intrinsic gene product characteristics at a genome-wide scale, is the identification of genes or sets of genes that behave in a manner associated to the biological process of interest. Subsequently, potential gene regulatory networks can be reconstructed based on this information, which can be compared to and fed back to knowledge from model species (Fig. 3). In this respect it is good to realize that for the usage of e.g. metabolomics data an additional hurdle needs to be taken in correlating metabolite concentrations to e.g. gene expression patterns and finally gene functions.

\section{Verification of gene function}

Both bottom-up and top-down approaches give a selection of genes that are potential key players in the biological process under study, and for which preferably the function should be validated. In Arabidopsis this is usually done through the selection of loss-offunction mutations in collections of T-DNA insertion plants (Slater et al., 2003). Alternatively, stable transformants can be generated or functions can be investigated based on transient expression assays by agro-infiltration or virus induced gene silencing (VIGS) (Lu et al., 2003, Yang et al., 2000). The majority of methods that are available today for gene function verification depend on transgenic approaches. Despite that these technologies are already available for thirty years and have undergone various improvements over the last decades, it is still far from trivial to transform any desired plant species. Therefore, it is still common practise to perform gene function verifications by overexpression or complementation studies using a model species as target (cross-species analysis) (Li et al., 2013, Tsaftaris et al., 2012).

\section{Examples of successful knowledge transfer to bulbous plants}

\section{Bottom-up "gene-by-gene" approach}

Several of the above discussed methods to transfer knowledge from model species to crops have been used already in bulbous species. Probably one of the best known examples of the bottom-up approach is related to the specification of floral organ identities by MADS box transcription factor genes according to the ABC-model (Ferrario et al., 2004, Litt and Kramer, 2010, Rijpkema et al., 2010). 
Floral organs in higher eudicots are organized in four concentric whorls, with sepals in the outer whorl, petals in whorl two, stamens in whorl three and carpels in the inner fourth whorl. The classical ABC model predicts the establishment of the four floral organ identities by the combinatorial action of MADS domain transcription factors and the accessory gene regulatory network appeared to be highly conserved. Based on the assumption that this network will also be conserved in bulbous flowers, hypotheses were generated to explain particular flower mutants in these species. Classical examples are the so called 'double flowers', in which stamens are converted into petals or petaloid organs, which in theory can be caused by alterations in B- or C-class MADS box genes. Expression studies in the double-flowered lily "Elodie" provided evidence that this phenotype indeed was caused by the miss-expression of the putative Lily Cclass gene LelAG1 (Akita et al., 2008). Besides the C class gene, a putative A class (AP1-like) and other MADS box genes of the $\mathrm{C} / \mathrm{D}$ class have been identified in Lilium longiflorum (Chen et al., 2008, Tzeng and Yang, 2001). Also in Crocus sativus a putative AP1 gene was identified as well as a SEPALLATA3 (SEP3)-like gene from the E-class (Tsaftaris et al., 2011, Tsaftaris et al., 2004). Despite strong conservations in flower organisation, plants belonging to the Liliaceae family have in general a slightly modified flower structure with two almost identical outer floral whorls, known as tepals. Based on this phenomenon a modified ABC model was proposed (van Tunen et al., 1993), suggesting that class B genes are also expressed in whorl one, leading to the same petaloid identity in the outer two whorls. The putative class B genes from Tulipa gesneriana were cloned and characterized (Kanno et al., 2003). In agreement with the hypothesized alternative model, the two DEFICIENS (DEF)-like genes TGDEFA and TGDEFB as well as one GLOBOSA (GLO)-like B-type gene TGGLO, were found to be all expressed in whorls one, two and three. The same model is also supported by the identification and analysis of B-class floral homeotic gene PISTILLATA (PI)/GLO in Crocus sativus (Kalivas et al., 2007). All together, these examples show the power of a "gene-by-gene" bottom-up approach in case of well-studied and strongly conserved biological processes.

\section{Top-down "transcriptome profiling" approach}

Performing large-scale expression studies coupled to phenotyping is an advanced technology to identify key genes involved in a particular biological process. In lily e.g., a custom-made cDNA microarray was designed and generated, consisting of several cDNA's obtained from different pollen-related tissues (Huang et al., 2006). Following, a differentially expressed gene was identified encoding for a putative protein containing ankyrin repeats and a RING zinc-finger domain, named LIANK. Comparison of LIANK to functionally characterized genes in model plants suggested ubiquitin ligase activity for the gene product. Further experiments could confirm this molecular function and revealed an important role for this gene in polar pollen tube growth, showing the relevance of the followed approach. Despite the potential of this method and the large number of examples of success stories in a variety of food crops, the approach has been hardly explored in bulbous plant species.

\section{Gene function verification using model species}

Upon the identification of functional analogues genes, verification of the function is an important process. Monocots are known to be recalcitrant to Agrobacterium-mediated transformation and there- fore most of the flower bulb transformations have been achieved through gene-gun techniques (e.g. (De Villiers et al., 2000, Kamo et al., 1995, Watad et al., 1998)). However, a major drawback of gene-gun transformation over Agrobacterium-mediated transformation is the lack of stable integrations on one hand and the unintended, but frequently observed integration of multiple gene copies in the case of a successful integration on the other hand. The latter can be a trigger for undesirable recombination events, genomic rearrangement, or silencing of the transgene (Hooykaas and Schilperoort, 1992). Conveniently, evidence has been provided for the presence of certain Agrobacterium strains being able to infect flower bulb species such as Ornithogalum (Van Emmenes et al., 2008), Gladiolus (Kamo et al., 1995) and Lilium (Cohen and Meredith, 1992). More recently Li and collaborators proved that insertion and stable integration of Zm401 gene in Lilium is possible via Agrobacterium-mediated transformation, which opens the door for more transgenic efforts in flower bulbs (Li et al., 2008). Nevertheless, in general transformation of bulbous plants is tedious and stable transformation frequencies are low (Lu et al., 2007, Wang et al., 2012). Therefore, heterologous complementation studies in Arabidopsis are widely used as an alternative to verify the function of a candidate gene found in bulbous species. For example, a homolog of CENTRORADIALIS (CEN)/TERMINAL FLOWER (TFL), CsatCEN/TFL1 respectively, was cloned from Crocus sativus and functionally characterized in Arabidopsis. In Arabidopsis, TFL controls axillary meristem identity, inflorescence development and flowering time (Alvarez et al., 1992). Overexpression of CsatCEN/ TFL1 in a tfl1 Arabidopsis mutant background resulted in complementation of the mutant phenotype, indicating that the gene isolated from C. sativus is able to function as TFL1 (Tsaftaris et al., 2012). A similar study revealed that a FT-like gene in Narcissus tazetta var. chinensis, known as NFT1, act as a flowering time regulator when ectopically and constitutively expressed in $\mathrm{ft}-3$ mutant Arabidopsis plants. In these transgenic lines, SOC1 a target of FT showed to be up-regulated as expected based on FT functioning in Arabidopsis (Li et al., 2013).

Besides stable transformation, transient technologies, such as VIGS, have been applied in bulbous species. A fragment of a putative PDS gene supposed to encoding phytoene desaturase, which is involved in carotenoid metabolism and photosynthesis, has e.g. been derived from lily and caused a bleaching phenotype in $N$. benthamiana after infiltration (VIGS). This phenotype was expected, because it is know that silencing of $P D S$ results in photo bleaching symptoms caused by a decrease in leaf carotene. This reveals that genes of monocot species can be used to silence their counterparts in the dicot $N$. benthamiana regardless of their distant evolutionary relationship (Benedito et al., 2004, Wang et al., 2009) and providing hints for possible functions of the used genes.

Although the above mentioned examples show the success and power of heterologous functional analyses based on stable or transient transformation, it is good to realize that these type of experiments do in principle not indicate more than that a gene from a crop has sufficient sequence homology and overlap in functional domains to take over the activity of the endogenous gene in the model system. Consequently, this is no guarantee that a similar function can be assigned to the identified gene in the crop species. Difference in the spatial or temporal expression pattern might already withhold the gene from its supposed function based on the heterologous functional analysis. 


\section{Future directions and challenges}

So far most molecular-oriented research studies in recalcitrant crops and bulbous plants have focussed on the identification of a single candidate gene. Analyses of complete regulatory pathways, as is nowadays common in model species, are hardly done yet. However, with the speed NGS technologies are developing (Schneeberger and Weigel, 2011), molecular technologies become attractive tools to analyse important biological processes in nonmodel species. Shahin and collegues (2012) provided e.g. the first transcriptome dataset of lily and tulip by sequencing of ESTs with the 454 NGS technology (Roche; http://www.454.com/). Comparative genomics helped with the search for gene conservation between tulip and lily, and the contigs could be annotated on the basis of the rice genome annotation (Sequencing Project International Rice, 2005). Subsequently, molecular function, biological process and cell component were predicted for the identified genes that all together resemble about $40 \%$ of the lily and tulip transcriptome. Hence, this approach provides fast insight in the active part of bulbous plants genomes, with a limited investment and avoiding the need for deciphering the complete genome sequence, which in the case of tulip is 200 times the size of the Arabidopsis genome. Although this is a great step forward, the authors realized and emphasized that deeper sequencing and analysis of time series for various tissues or cell types is essential to obtain sufficient information for extended comparative and functional gene studies. Furthermore, traditional sequencing techniques were producing long contiguous DNA sequence reads up to $1 \mathrm{~kb}$ in length; however, the majority of the latest introduced NGS platforms generate huge quantities of short sequence tags (50 to $100 \mathrm{bp}$ ), requiring sophisticated assembly algorithms and bioinformatics solutions (Reviewed in: (Nagarajan and Pop, 2013). Besides tackling this problem by a bioinformatic approach, technical improvements such as paired-end sequencing, helps to solve the assembly problem. Additionally, output from different platforms (e.g. PacBio; http://www.pacificbiosciences.com/) can be incorporated to overcome this problem to a certain extend. Nevertheless, the biggest barrier in this type of research will not be the generation of large scale data sets and the identification of complete gene sequences, but to extract the genes and alleles of importance for the process under study; or in other words, to find the needle in the haystack. In this respect it is good to take into account that the success rate of RNAseq experiments for gaining knowledge in a particular biological process strongly depends on a well-defined research question, followed by detailed temporal and spatial differential expression analyses (Van Verk et al., 2013). In addition to the correct input of biological material and the usage of optimal algorithms to extract genome-wide differential gene expression patterns, it is of utmost importance to improve the methods for the annotation of the identified genes. As discussed above, simple blast-based alignments are a good starting point, but in the case when no or only low homology exist with known gene sequences, other technologies are essential. Recently, bioinformatics and systems biology tools have been developed for this purpose, in which e.g. domain co-occurrence networks are generated (Wang et al., 2013) or information from various data sources or prediction programs is combined (Kourmpetis et al., 2011).

Despite the importance of bulbous plants for the ornamental industry, these species remained under investigated at the genetic and molecular level. However, thanks to the latest developments in transgenic research, the "omics" area, and in the field of systems biology, the detailed study of flowering and vegetative propagation in bulbous plants, resembling the two most important biological processes for agronomical improvements, comes in sight. In a breeders perspective, shortening of the juvenile phase will help increasing the speed of selection processes for new varieties, with e.g. improved bulb productivity, ornamental characteristics and pathogen resistance. Hopefully, these developments will keep this sector flourishing in the coming century.

\section{Acknowledgements}

We would like to thank Wilco Ligterink for critically reading of the manuscript and useful suggestions. Financial support for our research is provided by the Product Board of Horticulture (PT), TTI-Green Genetics, the Dutch Ministry of Economic Affairs, and the Royal General Association for Bulb Culture (KAVB).

\section{References}

AGI. (2000). Analysis of the genome sequence of the flowering plant Arabidopsis Thaliana. 408: 796-815.

AGUILAR-MARTíNEZ, J.A., POZA-CARRIÓN, C. and CUBAS, P. (2007). Arabidopsis Branched1 acts as an integrator of branching signals within axillary buds. Plant Cell 19: 458-472.

AKITA, Y., HORIKAWA, Y. and KANNO, A. (2008). Comparative analysis of floral MADS-box genes between wild-type and a putative homeotic mutant in lily. $J$ Hort Sci Biotech 83: 453-461.

ALONSO-PERAL, M.M., OLIVER, S.N., CASAO, M.C., GREENUP, A.A. and TREVASKIS, B. (2011). The Promoter of the Cereal VERNALIZATION1 Gene Is Sufficient for Transcriptional Induction by Prolonged Cold. PLOS ONE 6: e29456.

ALTSCHUL, S.F., GISH, W., MILLER, W., MYERS, E.W. and LIPMAN, D.J. (1990). Basic local alignment search tool. J Mol Biol 215: 403-410.

ALVAREZ, J., GULI, C.L., YU, X.-H. and SMYTH, D.R. (1992). terminal flower: a gene affecting inflorescence development in Arabidopsis Thaliana. Plant J 2: 103-116.

ANDRES, F. and COUPLAND, G. (2012). The genetic basis of flowering responses to seasonal cues. Nat Rev Genet 13: 627-639.

AUNG, L.H. and HERTOGH, A.A.D. (1979). Temperature Regulation of Growth and Endogenous Abscisic Acid-like Content of Tulipa gesneriana L. Plant Physiol 63: $1111-1116$

AXTELL, M.J., SNYDER, J.A. and BARTEL, D.P. (2007). Common Functions for Diverse Small RNAs of Land Plants. Plant Cell 19: 1750-1769.

BALASUBRAMANIAN, S. and WEIGEL, D. (2006). Temperature Induced Flowering in Arabidopsis Thaliana. Plant Signal Behav 1: 227-228.

BALK, P.A. and DE BOER, A.D. (1999). Rapid stalk elongation in tulip (Tulipa gesneriana L. Cv. Apeldoorn) and the combined action of cold-induced invertase and the water-channel protein $\gamma$ TIP. Planta 209: 346-354.

BEIJER. (1952). De ontwikkelingsstadia van tulp. Laboratorium voor Bloembollenonderzoek 92: 1-7.

BENEDITO, V.A., VISSER, P.B., ANGENENT, G.C. and KRENS, F.A. (2004). The potential of virus-induced gene silencing for speeding up functional characterization of plant genes. Genet Mol Res 3: 323-341.

BENNETT, T. and LEYSER, O. (2006). Something on the Side: Axillary Meristems and Plant Development. Plant Mol Biol 60: 843-854.

BENSCHOP, M., KAMENETSKY, R., LE NARD, M., OKUBO, H. and DE HERTOGH, A. (2010). The Global Flower Bulb Industry: Production, Utilization, Research. In Horticultural Reviews. John Wiley \& Sons, Inc., pp.1-115.

BINDSCHEDLER, L.V. and CRAMER, R. (2011). Quantitative plant proteomics. Proteomics 11: 756-775.

BOOKER, J., SIEBERER, T., WRIGHT, W., WILLIAMSON, L., WILLETT, B., STIRNBERG, P., TURNBULL, C., SRINIVASAN, M., GODDARD, P. and LEYSER, O. (2005). MAX1 encodes a cytochrome P450 family member that acts downstream of MAX3/4 to produce a carotenoid-derived branch-inhibiting hormone. Dev Cell 8: 443-449. 
BRAUN, N., GERMAIN, A.S., PILLOT, J.P., BOUTET-MERCEY, S., DALMAIS, M., ANTONIADI, I., LI, X., MAIA-GRONDARD, A., LE SIGNOR, C., BOUTEILLER, N. et al., (2012). The pea TCP transcription factor PsBRC1 acts downstream of strigolactones to control shoot branching. Plant Physiol 158: 225-238.

CHEN, M.-K., LIN, I.-C. and YANG, C.-H. (2008). Functional Analysis of Three Lily (Lilium longiflorum) APETALA1-like MADS Box Genes in Regulating Floral Transition and Formation. Plant Cell Physiol 49: 704-717.

CHOI, K., KIM, J., HWANG, H.-J., KIM, S., PARK, C., KIM, S.Y. and LEE, I. (2011). The FRIGIDAComplex Activates Transcription of FLC, a Strong Flowering Repressor in Arabidopsis, by Recruiting Chromatin Modification Factors. Plant Cell23:289-303.

COHEN, A. and MEREDITH, C.P. (1992). AGROBACTERIUM - MEDIATED TRANSFORMATION OF LILIUM. Acta Horticulture 325: 611-618.

COOKE, J.E.K., ERIKSSON, M.E. and JUNTTILA, O. (2012). The dynamic nature of bud dormancy in trees: environmental control and molecular mechanisms. Plant Cell Environ 35: 1707-1728.

DE VILLIERS, S.M., KAMO, K., THOMSON, J.A., BORNMAN, C.H. and BERGER, D.K. (2000). Biolistic transformation of chincherinchee (Ornithogalum) and regeneration of transgenic plants. Physiol Plantarum 109: 450-455.

FERRARIO, S., IMMINK, R.G.H. and ANGENENT, G.C. (2004). Conservation and diversity in flower land. Curr Opin Plant Biol 7: 84-91.

FINLAYSON, S.A. (2007). Arabidopsis TEOSINTE BRANCHED1-LIKE 1 Regulates Axillary Bud Outgrowth and is Homologous to Monocot TEOSINTE BRANCHED1. Plant Cell Physiol 48: 667-677.

FORNARA, F. and COUPLAND, G. (2009). Plant Phase Transitions Make a SPLash. Cell 138: 625-627.

GALVÃO, V.C., NORDSTRÖM, K.J.V., LANZ, C., SULZ, P., MATHIEU, J., POSÉ, D., SCHMID, M., WEIGEL, D. and SCHNEEBERGER, K. (2012). Synteny-based mapping-by-sequencing enabled by targeted enrichment. Plant J 71: 517-526.

GARBER, M., GRABHERR, M.G., GUTTMAN, M. and TRAPNELL, C. (2011). Computational methods for transcriptome annotation and quantification using RNA-seq. Nat Meth 8: 469-477.

GONZÁLEZ-GRANDÍO, E., POZA-CARRIÓN, C., SORZANO, C.O.S. and CUBAS, P. (2013). BRANCHED1 Promotes Axillary Bud Dormancy in Response to Shade in Arabidopsis. Plant Cell 25: 834-850.

GREB, T., CLARENZ, O., SCHÄFER, E., MÜLLER, D., HERRERO, R., SCHMITZ, G. and THERES, K. (2003). Molecular analysis of the LATERAL SUPPRESSOR gene in Arabidopsis reveals a conserved control mechanism for axillary meristem formation. Gene Dev 17: 1175-1187.

GREENUP, A.G., SASANI, S., OLIVER, S.N., TALBOT, M.J., DENNIS, E.S., HEMMING, M.N. and TREVASKIS, B. (2010). ODDSOC2 Is a MADS Box Floral Repressor That Is Down-Regulated by Vernalization in Temperate Cereals. Plant Physiol 153: 1062-1073.

HARTSEMA, A.M. (1961). Influence of temperature on flower formation and flowering of bulbous and tuberous plants. Encyclopedia of Plant Physiology 16, ed. W. Ruhland 123-167 Berlin: Springer verslag.

HOOYKAAS, P.J.J. and SCHILPEROORT, R.A. (1992). Agrobacterium and plant genetic engineering. Plant Mol Biol 20: 175-175

HORVATH, D. (2009). Common mechanisms regulate flowering and dormancy. Plant Science 177: 523-531.

HUANG, J., CHEN, F., DEL CASINO, C., AUTINO, A., SHEN, M., YUAN, S., PENG, J., SHI, H., WANG, C., CRESTI, M. et al., (2006). An Ankyrin Repeat-Containing Protein, Characterized as a Ubiquitin Ligase, Is Closely Associated with MembraneEnclosed Organelles and Required for Pollen Germination and Pollen Tube Growth in Lily. Plant Physiol 140: 1374-1383.

ISHIKAWA, S., MAEKAWA, M., ARITE, T., ONISHI, K., TAKAMURE, I. and KYOZUKA, J. (2005). Suppression of tiller bud activity in tillering dwarf mutants of rice. Plant Cell Physiol 46: 79-86.

IZAWA, T., TAKAHASHI, Y. and YANO, M. (2003). Comparative biology comes into bloom: genomic and genetic comparison of flowering pathways in rice and Arabidopsis. Curr Opin Plant Biol 6: 113-120.

KALIVAS, A., PASENTSIS, K., POLIDOROS, A. and TSAFTARIS, A. (2007). Heterotopic expression of B-class floral homeotic genes PISTILLATA/GLOBOSA supports a modified model for crocus (Crocus sativus L.) flower formation. DNA sequence 18: 120-130.

KAMENETSKY, R., ZACCAI, M. and FLAISHMAN, M.A. (2012). Florogenesis. In Ornamental Geophytes, (ed. KAMENETSKY, R. and OKUBO, H.). CRC Press.
KAMO, K., BLOWERS, A., SMITH, F., VAN ECK, J. and LAWSON, R. (1995). Stable Transformation of Gladiolus Using Suspension Cells and Callus. J Am Soc Hortic Sci 120: 347-352.

KANE, N.A., DANYLUK, J., TARDIF, G., OUELLET, F., LALIBERTÉ, J.-F., LIMIN, A.E., FOWLER, D.B. and SARHAN, F. (2005). TaVRT-2, a Member of the StMADS-11 Clade of Flowering Repressors, Is Regulated by Vernalization and Photoperiod in Wheat. Plant Physiol 138: 2354-2363.

KANNO, A., SAEKI, H., KAMEYA, T., SAEDLER, H. and THEISSEN, G. (2003). Heterotopic expression of class $B$ floral homeotic genes supports a modified ABC model for tulip (Tulipa gesneriana). Plant Mol Biol 52: 831-841.

KAUFMANN, K., SMACZNIAK, C., DE VRIES, S., ANGENENT, G.C. and KARLOVA, R. (2011). Proteomics insights into plant signaling and development. Proteomics 11: 744-755.

KEBROM, T.H., SPIELMEYER, W. and FINNEGAN, E.J. (2013). Grasses provide new insights into regulation of shoot branching. Trends Plant Sci 18: 41-48.

KELLER, T., ABBOTT, J., MORITZ, T. and DOERNER, P. (2006). Arabidopsis REGULATOR OF AXILLARY MERISTEMS1 controls a leaf axil stem cell niche and modulates vegetative development. Plant Cell 18: 598-611.

KOURMPETIS, Y.A.I., VAN DIJK, A.D.J., VAN HAM, R.C.H.J. and TER BRAAK, C.J.F. (2011). Genome-Wide Computational Function Prediction of Arabidopsis Proteins by Integration of Multiple Data Sources. Plant Physiol 155: 271-281.

KUMAR, S.V., LUCYSHYN, D., JAEGER, K.E., ALOS, E., ALVEY, E., HARBERD, N.P. and WIGGE, P.A. (2012). Transcription factor PIF4 controls the thermosensory activation of flowering. Nature 484: 242-245.

LAMBRECHTS, H., ROOK, F. and KOLLÖFFEL, C. (1994). Carbohydrate Status of Tulip Bulbs during Cold-Induced Flower Stalk Elongation and Flowering. Plant Physiol 104: 515-520.

LANG, A. (1952). Physiology of flowering. Ann Rev Plant Physiol 3: 265-306.

LEE, J.H., RYU, H.-S., CHUNG, K.S., POSÉ, D., KIM, S., SCHMID, M. and HOON AHN, J. (2013). Regulation of temperature-responsive flowering by MADS-box transcription factor repressors. Science doi:10.1126/science.1241097

LI, Q.-H., HONG, B., TONG, Z., MA, C., GUAN, A.-N., YU, J.-J. and GAO, J.-P. (2008) Establishment of regeneration system and transformation of Zm401 gene in Lilium longiflorum $\times$ L. formosanum. Chin J Agr Biotechnol 5: 113-119.

LI, X.-F., JIA, L.-Y., XU, J., DENG, X.-J., WANG, Y., ZHANG, W., ZHANG, X.-P., FANG, Q., ZHANG, D.-M., SUN, Y. et al., (2013). FT-Like NFT1 Gene May Play a Role in Flower Transition Induced by Heat Accumulation in Narcissus tazetta var. chinensis. Plant Cell Physiol 54: 270-281.

LI, X., QIAN, Q., FU, Z., WANG, Y., XIONG, G., ZENG, D., WANG, X., LIU, X., TENG, S., HIROSHI, F. et al., (2003). Control of tillering in rice. Nat Rev Mol Cell Biol 422: 618-621.

LITT, A. and KRAMER, E.M. (2010). The ABC model and the diversification of floral organ identity. Semin Cell Dev Biol 21: 129-137.

LIU, W., WU, C., FU, Y., HU, G., SI, H., ZHU, L., LUAN, W., HE, Z. and SUN, Z. (2009). Identification and characterization of HTD2: A novel gene negatively regulating tiller bud outgrowth in rice. Planta 230: 649-658.

LORENZ, M.G.O., CORTES, L.M., LORENZ, J.J. and LIU, E.T. (2003). Strategy for the Design of Custom cDNA Microarrays. Biotechniques 34: 1264-1270.

LU, G., ZOU, Q., GUO, D., ZHUANG, X., YU, X., XIANG, X. and CAO, J. (2007). Agrobacterium tumefaciens-mediated transformation of Narcissus tazzeta var. chinensis. Plant Cell Rep 26: 1585-1593.

LU, R., MARTIN-HERNANDEZ, A.M., PEART, J.R., MALCUIT, I. and BAULCOMBE, D.C. (2003). Virus-induced gene silencing in plants. Methods 30: 296-303.

LU, Y., HUGGINS, P. and BAR-JOSEPH, Z. (2009). Cross species analysis of microarray expression data. Bioinformatics 25: 1476-1483.

MARTIN, J.A. and WANG, Z. (2011). Next-generation transcriptome assembly. Nat Rev Genet 12: 671-682.

MCCOUCH, S.R. (2001). Genomics and Synteny. Plant Physiology 125: 152-155.

MOORE, S., PAYTON, P., WRIGHT, M., TANKSLEY, S. and GIOVANNONI, J. (2005) Utilization of tomato microarrays for comparative gene expression analysis in the Solanaceae. J ExpBot 56: 2885-2895

MORRIS, S.E., TURNBULL, C.G.N., MURFET, I.C. and BEVERIDGE, C.A. (2001) Mutational analysis of branching in pea. Evidence that Rms 1 and Rms 5 regulate the same novel signal. Plant Physiol 126: 1205-1213.

MÜLLER, D., SCHMITZ, G. and THERES, K. (2006). Blind homologous R2R3 Myb 
genes control the pattern of lateral meristem initiation in Arabidopsis. Plant Cell 18: 586-597.

NAGARAJAN, N. and POP, M. (2013). Sequence assembly demystified. Nat Rev Genet 14: 157-167.

NAPOLI, C. (1996). Highly branched phenotype of the petunia dad1-1 mutant is reversed by grafting. Plant Physiol 111: 27-37.

OIKAWA, T. and KYOZUKA, J. (2009). Two-Step Regulation of LAXPANICLE1 Protein Accumulation in Axillary Meristem Formation in Rice. Plant Cell 21: 1095-1108.

PODWYSZYŃSKA, M. (2005). Somaclonal variation in micropropagated tulips based on phenotype observation. J Fruit Ornam Plant Res 13: 109-122.

POSÉ, D., VERHAGE, L., OTT, F., YANT, L., MATHIEU, J., ANGENENT, G.C., IMMINK, R.G.H. and SCHMID, M. (2013). Temperature-dependent regulation of flowering by antagonistic FLM variants. Nature doi:10.1038/nature12633

REES, A.R. (1966). The Physiology of Ornamental Bulbous Plants. Bot Rev 32: 1-23. RIETVELD, P.L., WILKINSON, C., FRANSSEN, H.M., BALK, P.A., PLAS, L.H.W.V.D., WEISBEEK, P.J. and BOER, A.D.D. (2000). Low temperature sensing in tulip (tulipa gesneriana L.) is mediated through an increased response to auxin. $J$ Exp Bot 51 (2000)587-594.

RIJPKEMA, A.S., VANDENBUSSCHE, M., KOES, R., HEIJMANS, K. and GERATS, T. (2010). Variations on a theme: Changes in the floral ABCs in angiosperms. Sem Cell Dev Biol 21: 100-107.

SAITO, K. and MATSUDA, F. (2010). Metabolomics for Functional Genomics, Systems Biology, and Biotechnology. Ann Rev Plant Biol 61: 463-489.

SALENTIJN, E.J., PEREIRA, A., ANGENENT, G., LINDEN, C.G., KRENS, F., SMULDERS, M.M. and VOSMAN, B. (2007). Plant translational genomics: from model species to crops. Trends Plant Sci 20: 1-13.

SANIEWSKI, M., KAWA-MISZCZAK, L., WEGRZYNOWICZ-LESIAK, E. and OKUBO, $H$. (2000). Role of ABA, gibberellins and auxin in dormancy and dormancy release of tulip bulbs. CABI Publishing, Wallingford, pp.227-243.

SCHMITZ, G. and THERES, K. (2005). Shoot and inflorescence branching. Curr Opin Plant Biol 8: 506-511.

SCHNABLE, P.S.WARE, D.FULTON, R.S.STEIN, J.C.WEI, F.PASTERNAK, S.LIANG, C.ZHANG, J.FULTON, L.GRAVES, T.A. et al., (2009). The B73 Maize Genome: Complexity, Diversity, and Dynamics. Science 326: 1112-1115.

SCHNEEBERGER, K. and WEIGEL, D. (2011). Fast-forward genetics enabled by new sequencing technologies. Trends Plant Sci 16: 282-288.

SEQUENCING PROJECT INTERNATIONAL RICE, G. (2005). The map-based sequence of the rice genome. Nature 436: 793-800.

SHAHIN, A., VAN KAAUWEN, M., ESSELINK, D., BARGSTEN, J., VAN TUYL, J., VISSER, R.G. and ARENS, P. (2012). Generation and analysis of expressed sequence tags in the extreme large genomes Lilium and Tulipa. BMC Genomics 13: 640 .

SLATER, A., SCOTT, N.W. and FOWLER, M.R. (2003). Plant biotechnology: the genetic manipulation of plants. Oxford University Press, Oxford

SRIKANTH, A. and SCHMID, M. (2011). Regulation of flowering time: all roads lead to Rome. Cell Mol Life Sci 68: 2013-2037.

STRABLE, J., BORSUK, L., NETTLETON, D., SCHNABLE, P.S. and IRISH, E.E. (2008) Microarray analysis of vegetative phase change in maize. Plant J 56: 1045-1057.

SUN, C., SATHISH, P., AHLANDSBERG, S. and JANSSON, C. (1999). Analyses of isoamylase gene activity in wild-type barley indicate its involvement in starch synthesis. Plant Mol Biol 40: 431-443.

TANAKA, N., ITOH, H., SENTOKU, N., KOJIMA, M., SAKAKIBARA, H., IZAWA, T., ITOH, J.-I. and NAGATO, Y. (2011). The COP1 Ortholog PPS Regulates the Juvenile-Adult and Vegetative-Reproductive Phase Changes in Rice. Plant Cell 23: 2143-2154.

TREVASKIS, B., TADEGE, M., HEMMING, M.N., PEACOCK, W.J., DENNIS, E.S. and SHELDON, C. (2007). Short Vegetative Phase-Like MADS-Box Genes Inhibit Floral Meristem Identity in Barley. Plant Physiol 143: 225-235.

TSAFTARIS, A., PASENTSIS, K., KALIVAS, A., MICHAILIDOU, S., MADESIS, P. and ARGIRIOU, A. (2012). Isolation of a CENTRORADIALIS/TERMINAL FLOWER1 homolog in saffron (Crocus sativus L.): characterization and expression analysis. Mol Biol Rep 39: 7899-7910.
TSAFTARIS, A., PASENTSIS, K., MAKRIS, A., DARZENTAS, N., POLIDOROS, A. KALIVAS, A. and ARGIRIOU, A. (2011). The study of the E-class SEPALLATA3like MADS-box genes in wild-type and mutant flowers of cultivated saffron crocus (Crocus sativus L.) and its putative progenitors. J Plant Physiol 168: 1675-1684.

TSAFTARIS, A.S., PASENTSIS, K., ILIOPOULOS, I. and POLIDOROS, A.N. (2004). Isolation of three homologous AP1-like MADS-box genes in crocus (Crocus sativus L.) and characterization of their expression. Plant Sci 166: 1235-1243.

TZENG, T.-Y. and YANG, C.-H. (2001). A MADS Box Gene from Lily (Lilium Longiflorum) is Sufficient to Generate Dominant Negative Mutation by Interacting with PISTILLATA (PI) in Arabidopsis Thaliana. Plant Cell Physiol 42: 1156-1168.

VAN EMMENES, L., VEALE, A., COHEN, A. and ARAZI, T. (2008). Agrobacteriummediated transformation of the bulbous flower Ornithogalum. In Acta Horticulturae, vol. 766 (ed., pp. 477-484. Seoul).

VAN TUNEN, A.J., EIKELBOOM, W. and ANGENENT, G.C. (1993). Floral organogenesis in Tulipa. Flowering Newsletter 16: 33-38.

VAN VERK, M.C., HICKMAN, R., PIETERSE, C.M.J. and VAN WEES, S.C.M. (2013) RNA-Seq: revelation of the messengers. Trends Plant Sci 18: 175-179.

VENTURINI, L., FERRARINI, A., ZENONI, S., TORNIELLI, G.B., FASOLI, M., SANTO, S.D., MINIO, A., BUSON, G., TONONI, P., ZAGO, E.D. et al., (2013). De novo transcriptome characterization of Vitis vinifera cv. Corvina unveils varietal diversity. BMC Genomics 14: 41.

WANG, K., PENG, H., LIN, E., JIN, Q., HUA, X., YAO, S., BIAN, H., HAN, N., PAN, J., WANG, J. et al., (2010). Identification of genes related to the development of bamboo rhizome bud. J Exp Bot 61: 551-561.

WANG, M., WANG, G., JI, J. and WANG, J. (2009). The effect of pds gene silencing on chloroplast pigment composition, thylakoid membrane structure and photosynthesis efficiency in tobacco plants. Plant Sci 177: 222-226.

WANG, Y., KRONENBURG, B., MENZEL, T., MALIEPAARD, C., SHEN, X. and KRENS, F. (2012). Regeneration and Agrobacterium-mediated transformation of multiple lily cultivars. Plant Cell Tiss Organ Cult 111: 113-122.

WANG, Z., CAO, R. and CHENG, J. (2013). Three-Level Prediction of Protein Function by Combining Profile-Sequence Search, Profile-Profile Search, and Domain Co-Occurrence Networks. BMC Bioinformatics 14: S3.

WARD, S.P. and LEYSER, O. (2004). Shoot branching. Curr Opin Plant Biol 7: 73-78.

WATAD, A.A., YUN, D.J., MATSUMOTO, T., NIU, X., WU, Y., KONONOWICZ, A.K., BRESSAN, R.A. and HASEGAWA, P.M. (1998). Microprojectile bombardmentmediated transformation of Lilium longiflorum. Plant Cell Rep 17: 262-267.

XU, Y., BUCHHOLZ, W., DEROSE, R. and HALL, T. (1995). Characterization of a rice gene family encoding root-specific proteins. Plant Mol Biol 27: 237-248.

YAN, L., FU, D., LI, C., BLECHL, A., TRANQUILLI, G., BONAFEDE, M., SANCHEZ, A., VALARIK, M., YASUDA, S. and DUBCOVSKY, J. (2006). The wheat and barley vernalization gene VRN3 is an orthologue of FT. Proc Nat Acad Sci USA 103: 19581-19586

YAN, L., LOUKOIANOV, A., BLECHL, A., TRANQUILLI, G., RAMAKRISHNA, W. SANMIGUEL, P., BENNETZEN, J.L., ECHENIQUE, V. and DUBCOVSKY, J. (2004). The Wheat VRN2 Gene Is a Flowering Repressor Down-Regulated by Vernalization. Science 303: 1640-1644.

YANG, F., WANG, Q., SCHMITZ, G., MÜLLER, D. and THERES, K. (2012). The bHLH protein ROX acts in concert with RAX1 and LAS to modulate axillary meristem formation in Arabidopsis. Plant J 71: 61-70.

YANG, L., XU, M., KOO, Y., HE, J. and POETHIG, R.S. (2013). Sugar promotes vegetative phase change in Arabidopsis Thaliana by repressing the expression of MIR156A and MIR156C. eLife 2.

YANG, Y., LI, R. and QI, M. (2000). In vivo analysis of plant promoters and transcription factors by agroinfiltration of tobacco leaves. Plant $J$ 22: 543-551.

YU, S., CAO, L., ZHOU, C.-M., ZHANG, T.-Q., LIAN, H., SUN, Y., WU, J., HUANG J., WANG, G. and WANG, J.-W. (2013). Sugar is an endogenous cue for juvenileto-adult phase transition in plants. eLife 2.

ZHU, Q.-H. and HELLIWELL, C.A. (2011). Regulation of flowering time and flora patterning by miR172. J Exp Bot 62: 487-495. 


\section{Further Related Reading, published previously in the Int. J. Dev. Biol.}

The poetry of reproduction: the role of LEAFY in Arabidopsis Thaliana flower formation Nirodhini S. Siriwardana and Rebecca S. Lamb

Int. J. Dev. Biol. (2012) 56: 207-221

http://dx.doi.org/10.1387/ijdb.113450ns

\section{Chromatin remodeling in plant development}

José A. Jarillo, Manuel Piñeiro, Pilar Cubas and José M. Martínez-Zapater

Int. J. Dev. Biol. (2009) 53: 1581-1596

http://dx.doi.org/10.1387/ijdb.072460jj

\section{Genetic analysis of reproductive development in tomato}

Rafael Lozano, Estela Giménez, Beatriz Cara, Juan Capel and Trinidad Angosto

Int. J. Dev. Biol. (2009) 53: 1635-1648

http://dx.doi.org/10.1387/ijdb.072440rl

From phenotypic to molecular polymorphisms involved in naturally occurring variation of plant development

Carlos Alonso-Blanco, Belén Mendez-Vigo and Maarten Koornneef

Int. J. Dev. Biol. (2005) 49: 717-732

http://dx.doi.org/10.1387/ijdb.051994ca

Molecular genetic approaches to plant development

W Boerjan, B den Boer and $\mathrm{M}$ van Montagu

Int. J. Dev. Biol. (1992) 36: 59-66

http://dx.doi.org/10.1387/ijdb.1627476

5 yr ISI Impact Factor $(2011)=2.959$
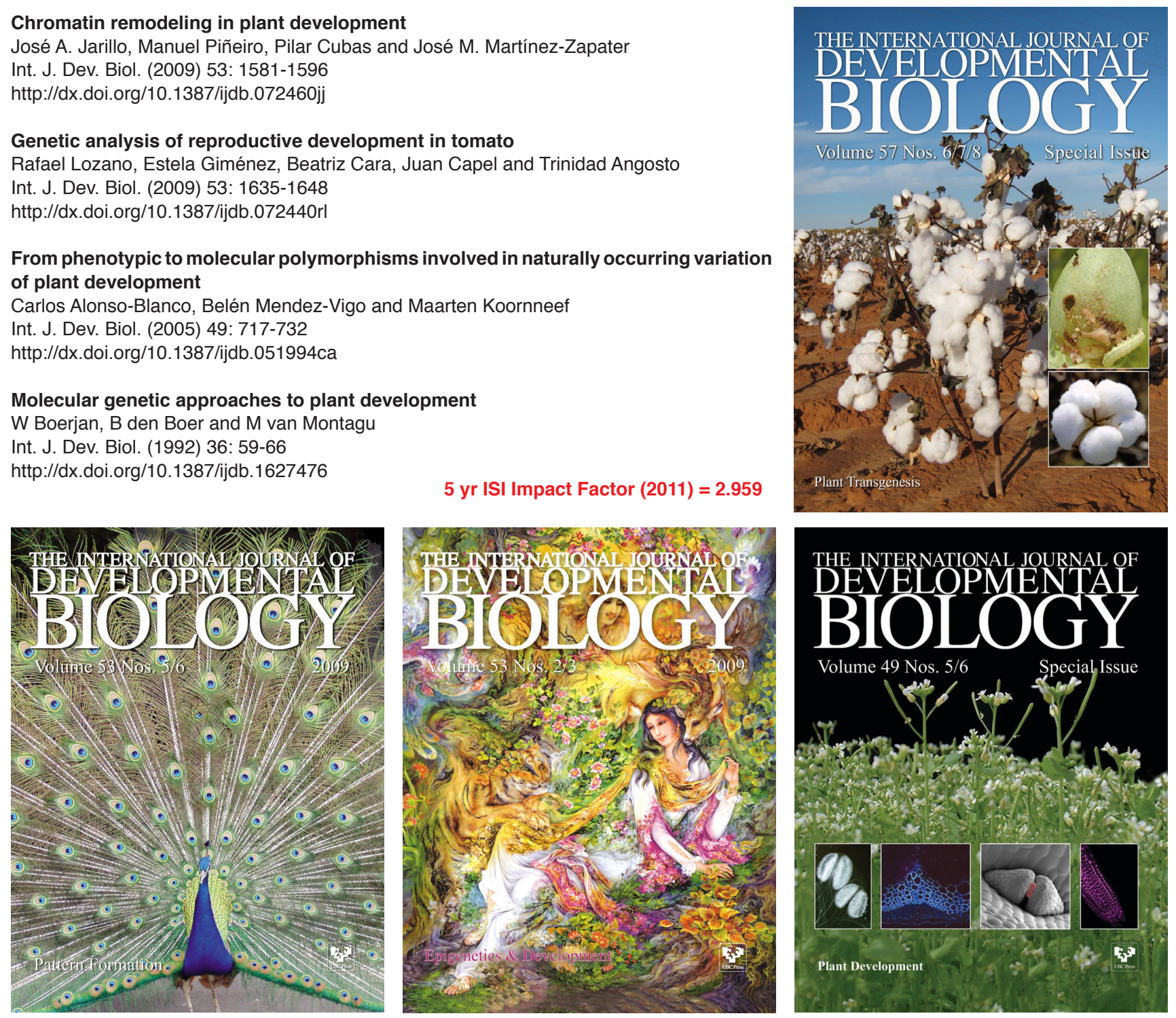